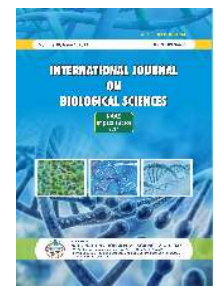

\title{
IN VITRO CYTOTOXIC AND APOPTOTIC EFFECT OF CONCANAVALINS FROM CANAVALIA spp. ON BREAST CARCINOMA CELLS
}

\author{
Geetha Suvarna ${ }^{1}$, Ashwini Prabhu ${ }^{2}$, Katheeja Muhseena ${ }^{2}$, Bhagya B. Sharma ${ }^{1}$ * \\ ${ }^{1}$ Centre for Environmental Studies, \\ ${ }^{2}$ Yenepoya Research Centre, \\ Yenepoya (Deemed to be University), Mangalore, Karnataka, India
}

Research Paper

Received: 18.05.2020

Revised: 25.05.2020

Accepted: 10.06.2020

ABSTRACT

Concanavalins from Canavalia spp. possess diverse bioactivities and exhibit potent anticancer effects. In this study we assessed the cytotoxic activity of concanavalins from Canavalia spp. on human breast carcinoma MCF-7 cells. The lectins concanavalin A (ConA), concanavalin C (ConC), concanavalin G (ConG) and concanavalin M (ConM) were isolated from seeds of C. ensiformis, C. cathartica, C. gladiata and C. rosea respectively. ConA and ConG demonstrated strong inhibitory effect on MCF-7 cell proliferation with $\mathrm{IC}_{50}$ values $81.66 \mu \mathrm{g} / \mathrm{mL}$ and $81.09 \mu \mathrm{g} / \mathrm{mL}$ respectively, with no significant effect in normal kidney HEK293T cells. MCF-7 cells treated with ConA and ConG showed apoptotic morphological changes and accumulation of sub- $\mathrm{G}_{0} / \mathrm{G}_{1}$ proportion, suggesting stimulation of apoptotic pathway. These results uphold the anticancer potential of concanavalins.

Keywords: Concanavalin, Cytotoxicity, Apoptosis, Cell cycle, MCF-7 cells.

\section{INTRODUCTION}

Lectins are proteins that bind to specific carbohydrates reversibly without modifying them and are prevalent in bacteria, fungi, plants and animals (Sharon, 2007). Because of their carbohydrate binding ability, lectins have found a special place in biomedical field including cancer research. Plant lectins can bind to tumor cell surface and induce apoptosis or autophagy (Bhutia et al., 2019). Lectins can specifically differentiate cancer cells from the normal ones and can therefore act as valuable tool in cancer research (Poiroux et al., 2017).

Legume lectins are a group of lectins which share high homology with a significant number of conserved amino acid residues. They are widely explored for their structure and different biological functions. Concanavalin A(ConA) is the first lectin isolated and crystallized by Sumner and Howell (1936) from the seeds of leguminous plant,
Canavalia ensiformis. This mannose/glucose specific lectin is renowned for its biological functions like agglutination, mitogenicity, antimicrobial, insecticidal and anticancer properties (see Suvarna and Sharma, 2018).

ConA is shown to inhibit proliferation of cancer cells in vitro and in vivo. ConA induced cytotoxicity by triggering apoptotic response in human leukemic (MOLT-4 and HL60), glioblastoma (U87) and breast cancer (MCF-7) cells with no damage to normal cells (Faheina-Martins et al., 2012; Pratt et al., 2012; Shi et al., 2014). Apoptotic cell death was induced by down-regulation of NF-kB, ERK, JNK in MCF-7 cells and inhibition of Akt-Foxo1a-Bim pathway in p53 null cells (Shi et al., 2014; Amin et al., 2007). The in vivo antitumor effect of ConA was observed in mice bearing MCF-7 cell xenografts (Shi et al., 2014). ConA is also used as a diagnostic tool in cancer research. ConA adhered onto graphene quantum dots were used as

*Corresponding author: bagyabs@gmail.com 
nanosensing probe for quantitative determination of cancer cells (Chowdhury et al., 2019). The application of ConA as a drug delivery system improved the cell targeting efficacy of apigenin (chemotherapeutic agent) in skin cancer cells (Jangdey et al., 2019).

Concanavalin C (ConC), concanavalin G (ConG) and concanavalin $\mathrm{M}$ (ConM) from $C$. cathartica, $C$. gladiata and $C$. rosea respectively are the unexploited molecules with reports on agglutination, mitogenic, antibacterial, anti-inflammatory and vasorelaxant activity (see Suvarna and Sharma, 2018; Cavada et al., 2019). The cytotoxic effect of ConG on mouse B16 melanoma cell and mouse L1210 leukemia cells has been reported (Wong and Ng, 2005; Une et al., 2019). ConM showed potent antiproliferative effect in human ovarian cancer A2780 and lung cancer A549 cells (Gondim et al., 2017). Likewise, ConC affected proliferation of rat C6 glioma cells (Osterne et al., 2017). In the present study, cytotoxic effect of ConC, ConG and ConM on human breast carcinoma MCF-7 cells in comparison to ConA is reported.

\section{MATERIALSAND METHODS}

\section{Chemicals and reagents}

Dulbecco's modified eagle medium (DMEM), antibiotic-antimycotic solution, fetal bovine serum (FBS), trypsin-EDTA solution and 3-(4,5dimethylthiazol-2-yl)-2,5-diphenyltetrazolium bromide (MTT) were procured from Himedia, India. Acridine orange, ethidium bromide and dimethyl sulfoxide (DMSO) were obtained from Merck, India.

\section{Extraction of lectin from Canavalia seeds}

Seeds of $C$. ensiformis were collected from Vittal $\left(12^{\circ} 45^{\prime} 55.9^{\prime \prime} \mathrm{N}, 7^{\circ} 05^{\prime} 56.4^{\prime \prime} \mathrm{E}\right), \quad$ C. cathartica from Kallapu (1249'47.3"N, 7451'35.2"E), C. gladiata from Adyanadka (12 $\left.{ }^{\circ} 69^{\prime} 54.2^{\prime \prime} \mathrm{N}, 7^{\circ} 10^{\prime} 77.5^{\prime \prime} \mathrm{E}\right)$ and C. rosea from Tannirbavi (1288'67.7"N, 7481'51.7"E) of Dakshina Kannada District, Karnataka, India. Seed samples were authenticated by a plant taxonomist. Lectins were extracted from seed cotyledon by saltingout method (Khan and Naeem, 2011). Cotyledon powder was homogenized in $0.15 \mathrm{M} \mathrm{NaCl}$ [1:10 (w:v)] using mortar and pestle. The homogenate was filtered and subjected to ammonium sulphate precipitation at different saturation levels (0-20\%, 20-40\%, 40-60\%, 60$80 \%$ and $80-100 \%)$. The protein precipitate fraction with maximum specific activity was dialyzed against distilled water, dried (Speed Vac vacuum concentrator) and used for further experiments. At each phase of the purification process, protein was quantified by Lowry's method (Waterborg and Matthews, 1994). Specific activity was determined by hemagglutination assay and expressed as hemagglutination units per mg of protein (HU/mg). Hemagglutination assay is a simple method for detection of lectins which are capable of agglutinating erythrocytes (Hankins et al., 1980). The assay was performed in human erythrocytes by collecting peripheral blood with consent from healthy individual. The experimental protocol was approved by Institutional Ethics Committee (Protocol number 2018/052).

\section{Cell lines and culture conditions}

Human breast carcinoma MCF-7 and normal human embryonic kidney HEK293T cell lines were procured from National Centre for Cell Sciences (NCCS), Pune, India. The cell lines were cultured in DMEM growth medium (supplemented with 10\% FBS and 1\% antibiotic-antimycotic solution) at $37^{\circ} \mathrm{C}$ in a humidified incubator with $5 \% \mathrm{CO}_{2}$. The cells were harvested on attaining $70 \%$ confluence and plated at desired concentration for different experiments.

\section{Determination of cytotoxicity}

The cytotoxicity of concanavalins on breast carcinoma MCF-7 and normal kidney HEK293T cells was determined by MTT assay (Mosmann, 1983). The cells were plated at $5 \times 10^{3}$ cells/well density in a 96-well plate. The concanavalins were added at concentrations ranging from 12.5 to $800 \mu \mathrm{g} / \mathrm{mL}$ in triplicates and treated for $24 \mathrm{~h}$ at $37^{\circ} \mathrm{C}$. Cells without concanavalin treatment served as control. The MTT reagent (1 $\mathrm{mg} / \mathrm{mL}$ ) was added to each well and incubated for $4 \mathrm{~h}$ at $37^{\circ} \mathrm{C}$. Culture medium was aspirated and $100 \mu \mathrm{L}$ of DMSO was added to dissolve formazan crystals. Absorbance at $570 \mathrm{~nm}$ was measured using multimode microplate reader (FluoSTAR Omega, BMG Labtech, Germany). The percentage viability of cells was calculated by

$$
\left[\left(\mathrm{OD}_{\text {control }}-\mathrm{OD}_{\text {test }}\right) / \mathrm{OD}_{\text {control }}\right] \times 100 .
$$

Dose-response curve was plotted using percentage viability against concentration and $\mathrm{IC}_{50}$ value was estimated.

\section{Assessment of cell morphology}

Alterations in MCF-7 cell morphology induced by ConA and ConG were observed by acridine orange/ethidium bromide (AO/EB) dual staining method (Liu et al., 2015). The MCF-7 cells $\left(2 \times 10^{4}\right.$ cells/well) were seeded into 12 -well plate and treated with $\mathrm{IC}_{50}$ and $1 / 2 \mathrm{IC}_{50}$ concentrations of concanavalins in 
triplicates for $24 \mathrm{~h}$ at $37^{\circ} \mathrm{C}$. The untreated cells served as control. The cells were fixed in cold methanol for 30 min. The AO $(2 \mu \mathrm{g} / \mathrm{ml})$ and EB $(2 \mu \mathrm{g} / \mathrm{ml})$ staining solution was added to each well and incubated at $37^{\circ} \mathrm{C}$ for $15 \mathrm{~min}$. Cells were washed with phosphate buffered saline to remove excess stain. Morphological changes were observed under fluorescent cell imager (ZOE, BioRad, USA) with blue excitation filter (B-2A) at 20X magnification.

\section{Cell cycle analysis}

MCF-7 cells were seeded into 12-well plate at a density of $2 \times 10^{4}$ cells/well. The cells were treated with $\mathrm{IC}_{50}$ and $1 / 2 \quad \mathrm{IC}_{50}$ concentrations of ConA and ConG in triplicates for $24 \mathrm{~h}$ at $37^{\circ} \mathrm{C}$. Untreated MCF-7 cells served as control. The cells were harvested, washed with PBS and resuspended in fluorochrome solution (comprising $5 \mu \mathrm{g} / \mathrm{mL}$ propidium iodide, $0.1 \%$ Triton X-100 and $100 \mu \mathrm{g} / \mathrm{mL}$ RNase A). Cells were analysed in a flow cytometer (Guava EasyCyte, Merck Millipore, USA) and cell proportions at different cell cycle phases were quantified using Flowing software v2.5.1(Terho, 2012).

\section{Statistical analysis}

Statistical analysis was performed using Statistical Package for Social Sciences (SPSS) software version 23.0. The data was expressed as mean \pm SD of triplicate treatment groups. Treatment groups were compared with control by one-way ANOVA followed by Tuckey's posthoc test with level of significance at $\mathrm{p}<0.05$.

\section{RESULTS}

\section{Lectin extraction:}

Homogenised seed extract was purified by ammonium sulfate precipitation at different saturation levels (020\%, 20-40\%, 40-60\%, 60-80\%, 80-100\%). A gradual increase in specific activity was observed in precipitated fractions with a maximum activity at 40$60 \%$ saturation level above which decline in the activity was observed. The 40-60\% fraction of ConA, ConC, ConG and ConM was further dialysed against distilled water to obtain a final product with specific activity of 1931.96, 11564.01, 21692 and 10867.07 $\mathrm{HU} / \mathrm{mg}$ respectively. The hemagglutination activity in purified concanavalins was $34-38 \%$ compared to their crude extract (Table 1 ).

Table 1: Purification, total protein and hemagglutination activity of concanavalins by salting-out method.

\begin{tabular}{|c|c|c|c|c|c|}
\hline Concanavalins & Purification stage & $\begin{array}{c}\text { Total } \\
\text { protein }(\mathrm{mg})\end{array}$ & $\begin{array}{c}\text { Specific activity } \\
(\mathrm{HU} / \mathrm{mg})^{\mathrm{a}}\end{array}$ & $\begin{array}{l}\text { Purification } \\
\text { fold }^{\text {b }}\end{array}$ & $\begin{array}{c}\text { Recovery } \\
(\%)^{c}\end{array}$ \\
\hline \multirow[t]{3}{*}{ ConA } & Crude extract & 6667.83 & 1036.62 & 1.00 & 100.00 \\
\hline & $\begin{array}{l}40-60 \% \text { Ammonium } \\
\text { sulphate fraction }\end{array}$ & 1355.03 & 2267.11 & 2.19 & 44.44 \\
\hline & Dialysis & 1225.70 & 1931.96 & 1.86 & 34.26 \\
\hline \multirow[t]{3}{*}{ ConC } & Crude extract & 7831.23 & 7159.03 & 1.00 & 100.00 \\
\hline & $\begin{array}{l}\text { 40-60\% Ammonium } \\
\text { sulphate fraction }\end{array}$ & 2603.40 & 10029.95 & 1.40 & 46.58 \\
\hline & Dialysis & 1859.56 & 11564.01 & 1.62 & 38.36 \\
\hline \multirow[t]{3}{*}{ ConG } & Crude extract & 6251.14 & 8927.65 & 1.00 & 100.00 \\
\hline & $\begin{array}{l}\text { 40-60\% Ammonium } \\
\text { sulphate fraction }\end{array}$ & 1337.47 & 19140.56 & 2.14 & 45.87 \\
\hline & Dialysis & 944.13 & 21692.00 & 2.43 & 36.70 \\
\hline \multirow[t]{3}{*}{ ConM } & Crude extract & 7705.76 & 7242.37 & 1.00 & 100.00 \\
\hline & $\begin{array}{l}40-60 \% \text { Ammonium } \\
\text { sulphate fraction }\end{array}$ & 2518.41 & 10165.16 & 1.40 & 45.87 \\
\hline & Dialysis & 1884.59 & 10867.07 & 1.50 & 36.70 \\
\hline
\end{tabular}

${ }^{\mathrm{a}}$ Specific activity of purified lectin was expressed as hemagglutination units (HU) per mg of protein; ${ }^{\mathrm{b}}$ Purification fold is the fold increase in specific activity with respect to crude extract; ${ }^{c}$ Recovery of activity (\%) is the measure of agglutination activity retained compared to crude extract. 


\section{Cell viability of MCF-7 and HEK293T cells}

Treatment of MCF-7 cells with concanavalins showed inhibition of proliferation in a dose-dependent manner. Significant decrease in cell viability was observed upto $200 \mu \mathrm{g} / \mathrm{mL}(\mathrm{p}<0.001)$ compared to untreated MCF-7 cells (Fig. 1A) and with no significant inhibition up to $100 \mu \mathrm{g} / \mathrm{mL}$ in normal HEK293T cells (Fig. 1B). The growth inhibitory effect of ConA $\left(\mathrm{IC}_{50}\right.$ value -81.66 $\mu \mathrm{g} / \mathrm{mL})$ and ConG $\left(\mathrm{IC}_{50}\right.$ value $\left.-81.09 \mu \mathrm{g} / \mathrm{mL}\right)$ on MCF-7 cells was more evident than ConC ( IC $_{50}$ value $100.28 \mu \mathrm{g} / \mathrm{mL}$ ) and ConM ( $\mathrm{IC}_{50}$ value - 104.47 $\mu \mathrm{g} / \mathrm{mL})$. Based on cell viability results ConA and ConG were further evaluated for their effect on cell morphology and to study the relative frequency of cells in different phases of cell cycle in MCF-7 cells.

\section{Apoptotic cell death induced by concanavalins}

ConA and ConG induced apoptotic morphological changes like chromatin condensation, nuclear fragmentation and formation of apoptotic bodies in MCF-7 cells. Untreated cells showed green fluorescence with viable nuclei and typical cellular morphology. Cells treated with $1 / 2 \mathrm{IC}_{50}$ concentration of ConG revealed early apoptotic cells with yellowish green fluorescence and at $\mathrm{IC}_{50}$ concentration late apoptotic cells with orange fluorescence were observed. ConA showed early apoptosis with dosedependent decrease in viable cells compared to untreated and ConG treated MCF-7 cells (Fig. 2).

\section{Cell cycle distribution of concanavalin treated MCF-7 cells}

The histogram plots acquired from flow cytometry showed significant increase in sub- $\mathrm{G}_{0} / \mathrm{G}_{1}$ proportion in concanavalin-treated MCF-7 cells with respect to control thus indicating apoptotic cell death. Dosedependent increase in sub- $G_{0} / G_{1}$ proportion was observed in MCF-7 cells treated with ConA $\left(\mathrm{IC}_{50}-71.3\right.$ $\pm 2.5 \%$ and $\left.1 / 2 \mathrm{IC}_{50}-31.5 \pm 3.8 \%\right)$ and $\mathrm{ConG}\left(\mathrm{IC}_{50}-67.1\right.$ $\pm 3.4 \%$ and $\left.1 / 2 \mathrm{IC}_{50}-26.5 \pm 3.5 \%\right)$ compared to control $(14.7 \pm 2.3 \%)$ (Fig. 3).

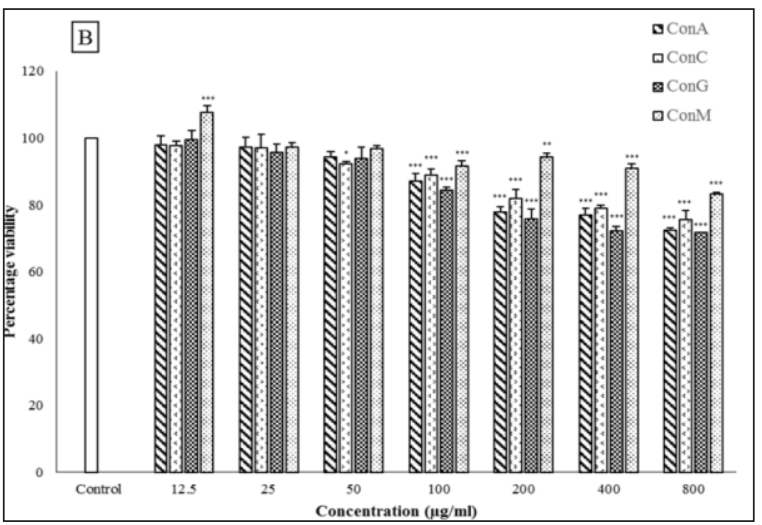

Fig. 1: Cytotoxicity of concanavalins in breast carcinoma MCF-7 (A) and normal kidney HEK293T (B) cells. Data is expressed as mean $\pm S D$. Percent viability for test concentrations differed significantly from control $\left({ }^{*} p<0.05\right.$, ${ }^{* *} p<0.01$, *** $p<0.001$; one-way ANOVA).

\section{DISCUSSION}

Lectins possess many biological activities and selectively bind to cancer cells (Sharon, 2007; Poiroux et al., 2017). In this study, concanavalins were isolated from Canavalia spp. and studied for their cytotoxic potential in human breast carcinoma MCF-7 cells. The cell viability assay results indicated potential cytotoxic activity of concanavalins with ConA and ConG being more effective than ConC and ConM. Although these homologous proteins show minor difference in their genetic and protein structure, they show significant variation in biological properties (Bezerra et al., 2011;
Arruda et al., 2013; Suvarna and Sharma, 2020). This differential activity is due to change in volume and configuration of sugar binding site and $\mathrm{pH}$-dependent oligomerization (Mandal and Brewer, 1993; Bezerra et al., 2011; Arruda et al., 2013). Moreover, these concanavalins were found to be least toxic towards normal kidney HEK293T cells. Lectin binding affinity towards cancer cells varies from normal cells due to altered glycosylation pattern on their surface (Poiroux et al., 2017). According to Liu et al., (2013), breast cancer cells over-express high-mannose glycans compared to normal epithelial cell line. The selective 


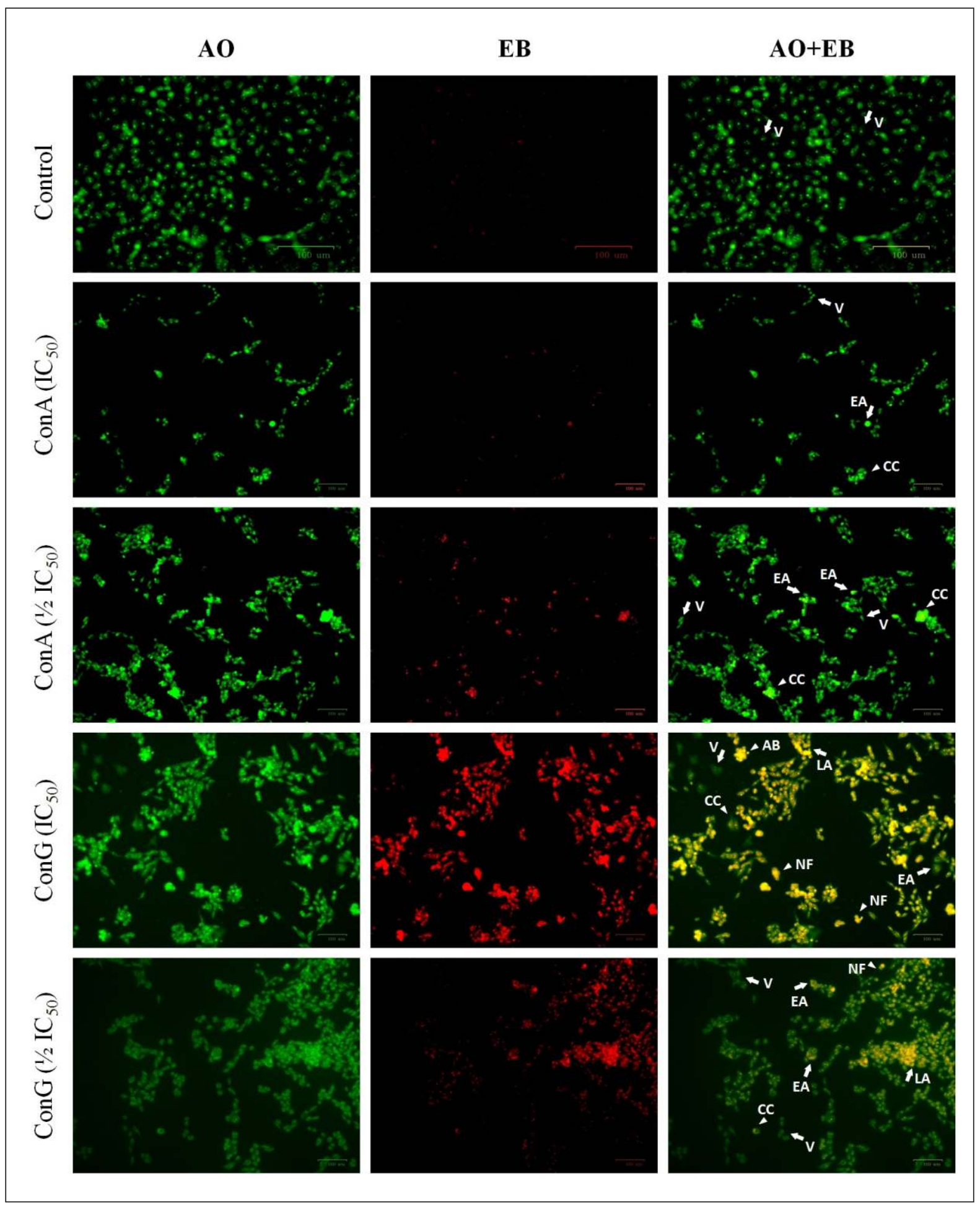

Fig. 2: Morphological changes induced by ConA and ConG in MCF-7 cells.

Photomicrographs of AO/EB stained MCF-7 cells captured using green and red channels (scale bar - 100 $\mu \mathrm{m})$. Labels: V-viable cell, EA-early apoptosis, LA-late apoptosis, CC-chromatin condensation, NF-nuclear fragmentation, AB-apoptotic body. 


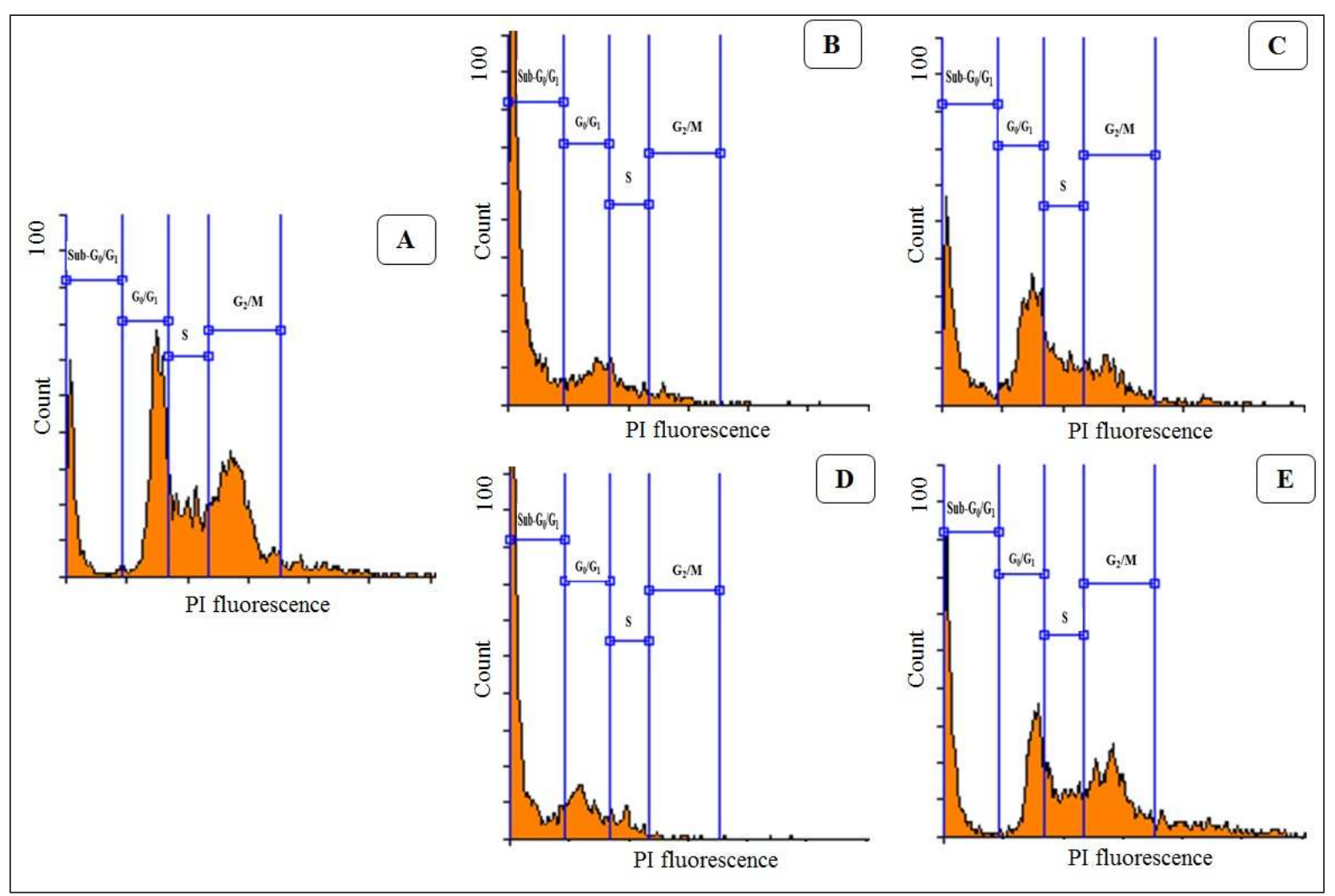

Fig. 3: Effect of ConA and ConG on cell cycle phases in MCF-7 cells.

Flow cytometric histograms of untreated MCF-7 cells (A); Cells treated with $I_{50}(B)$ and $1 / 2 I_{50}(C)$ concentrations of ConA; Cells treated with $I C_{50}(D)$ and $1 / 2 I_{50}(E)$ concentrations of ConG.

toxicity exhibited by mannose-specific concanavalins supports this observation.

ConA and ConG were further studied in detail for their mechanism of action in MCF-7 cells. AO/EB staining data suggested apoptotic cell death wherein the MCF-7 cells treated with concanavalins exhibited chromatin condensation, nuclear fragmentation and apoptotic body. The apoptotic potential of these concanavalins was further supported by cell cycle analysis using flow cytometry, which showed accumulation of sub$\mathrm{G}_{0} / \mathrm{G}_{1}$ cell population upon treatment with ConA and ConG. Plant lectins are shown to induce anticancer effect mainly through apoptotic mechanism (Bhutia et al., 2019). ConA is reported to elicit apoptosis in human melanoma A375, leukemic MOLT-4, HL-60 and hepatoma HepG2 cells (Liu et al., 2009; Liu et al., 2010; Faheina-Martins et al., 2012). Lectins trigger apoptosis by binding to sugar moieties of glycoprotein or glycolipid on the cell surface (Kim et al., 1993). The antiproliferative activity of ConA is positively correlated with carbohydrate binding (Liu et al., 2010). Recent studies have demonstrated that, ConA trigger mitochondria-mediated apoptotic pathway by collapse of mitochondrial membrane potential, activation of caspase-3/9 and release of cytochrome C (Liu et al., 2009; Liu et al., 2010; Faheina-Martins et al., 2012). ConA induced apoptosis by inhibition of AKT pathway and activation of p73-Foxo1a-Bim signaling pathway (Amin et al., 2007). It also induced down-regulation of cell signalling genes such as NFкB, ERK, JNK and up-regulation of p53 and p21 (Shi etal., 2014).

\section{CONCLUSION}

The concanavalins showed cytotoxicity in breast carcinoma MCF-7 cells with no deleterious effect in normal cells. ConA and ConG demonstrated antiproliferative activity in MCF-7 cells by stimulating apoptotic mechanism. These activities of concanavalins make them potential candidates for cancer diagnosis and as anticancer therapeutics. 


\section{ACKNOWLEDGEMENTS}

First author acknowledges Yenepoya (Deemed to be University) for providing the junior research fellowship.

\section{CONFLICT OF INTEREST}

The authors declare that they have no conflict of interest.

\section{REFERENCES}

1. Amin, A.R., Paul, R.K., Thakur, V.S. and Agarwal, M.L. (2007). A novel role for p73 in the regulation of Akt-Foxo1a-Bim signaling and apoptosis induced by the plant lectin, Concanavalin A. Cancer Res. 67(12):5617-5621.

2. Arruda, F.V., Melo, A.A., Vasconcelos, M.A., Carneiro, R.F., Barroso-Neto, I.L., Silva, S.R., Pereira-Junior, F.N., Nagano, C.S., Nascimento, K.S., Teixeira, E.H. and SakerSampaio, S. (2013). Toxicity and binding profile of lectins from the Genus Canavalia on brine shrimp. BioMed Res. Int. e154542.

3. Bezerra, E.H., Rocha, B.A., Nagano, C.S., de Arruda Bezerra, G., de Moura, T.R., Bezerra, M.J., Benevides, R.G., Sampaio, A.H., Assreuy, A.M., Delatorre, P. and Cavada, B.S. (2011). Structural analysis of ConBr reveals molecular correlation between the carbohydrate recognition domain and endothelial NO synthase activation. Biochem. Biophys. Res. Commun. 408(4):566-570.

4. Bhutia, S.K., Panda, P.K., Sinha, N., Praharaj, P.P., Bhol, C.S., Panigrahi, D.P., Mahapatra, K.K., Saha, S., Patra, S., Mishra, S.R. and Behera, B.P. (2019). Plant lectins in cancer therapeutics: Targeting apoptosis and autophagydependent cell death. Pharmacol. Res. 144:8-18.

5. Cavada, B.S., Pinto-Junior, V.R., Osterne, V.J. and Nascimento, K.S. (2019). ConA-like lectins: high similarity proteins as models to study structure/biological activities relationships. Int. J. Mol. Sci. 20(1):30.

6. Chowdhury, A.D., Ganganboina, A.B., Park, E.Y. and Doong, R.A. (2018). Impedimetric biosensor for detection of cancer cells employing carbohydrate targeting ability of Concanavalin A. Biosens. Bioelectron. 122:95-103.

7. Faheina-Martins, G.V., da Silveira, A.L., Cavalcanti, B.C., Ramos, M.V., Moraes, M.O., Pessoa, C. and Araújo, D.A. (2012).
Antiproliferative effects of lectins from Canavalia ensiformis and Canavalia brasiliensis in human leukemia cell lines. Toxicol. In Vitro. 26(7):1161-1169.

8. Gondim, A.C., Romero-Canelón, I., Sousa, E.H., Blindauer, C.A., Butler, J.S., Romero, M.J., Sanchez-Cano, C., Sousa, B.L., Chaves, R.P., Nagano, C.S. and Cavada, B.S. (2017). The potent anti-cancer activity of Dioclea lasiocarpa lectin. J. Inorg. Biochem. 175:179189.

9. Hankins, C.N., Kindinger, J.I. and Shannon, L.M. (1980). Legume alpha-galactosidases which have hemagglutinin properties. Plant Physiol. 65(4):618-622.

10. Jangdey, M.S., Kaur, C.D. and Saraf, S. (2019). Efficacy of Concanavalin-A conjugated nanotransfersomal gel of apigenin for enhanced targeted delivery of UV induced skin malignant melanoma. Artif. Cells Nanomed. Biotechnol. 47(1):904-916.

11. Khan, T.A. and Naeem, A. (2011). An alternate high yielding inexpensive procedure for the purification of concanavalin A. Biol Med. 3(2):250-259.

12. Kim, M., Rao, M.V., Tweardy, D.J., Prakash, M., Galili, U. and Gorelik, E. (1993). Lectininduced apoptosis of tumour cells. Glycobiology. 3(5):447-453.

13. Liu, B., Li, C.Y., Bian, H.J., Min, M.W., Chen, L.F. and Bao, J.K. (2009). Antiproliferative activity and apoptosis-inducing mechanism of Concanavalin A on human melanoma A375 cells. Arch. Biochem. Biophys. 482(1-2):1-6.

14. Liu, K., Liu, P.C., Liu, R. and Wu, X. (2015). Dual AO/EB staining to detect apoptosis in osteosarcoma cells compared with flow cytometry. Med Sci Monit Basic Res. 21:15-20.

15. Liu, X., Nie, H., Zhang, Y., Yao, Y., Maitikabili, A., Qu, Y., Shi, S., Chen, C. and Li, Y. (2013). Cell surface-specific N-glycan profiling in breast cancer. PLoS One. 8(8):e72704.

16. Liu, Z., Li, X., Ding, X. and Yang, Y. (2010). In silico and experimental studies of concanavalin A: insights into its antiproliferative activity and apoptotic mechanism. Appl. Biochem. Biotechnol.162(1):134-145. 
17. Mandal, D.K. and Brewer, C.F. (1993). Differences in the binding affinities of dimeric concanavalin A (including acetyl and succinyl derivatives) and tetrameric concanavalin A with large oligomannose-type glycopeptides. Biochemistry. 32(19):5116-5120.

18. Mosmann, T. (1983). Rapid colorimetric assay for cellular growth and survival: application to proliferation and cytotoxicity assays. J. Immunol. Methods. 65(1-2):55-63.

19. Osterne, V.J., Silva-Filho, J.C., Santiago, M.Q., Pinto-Junior, V.R., Almeida, A.C., Barreto, A.A., Wolin, I.A., Nascimento, A.P., Amorim, R.M., Rocha, B.A. and Delatorre, P. (2017). Structural characterization of a lectin from Canavalia virosa seeds with inflammatory and cytotoxic activities. Int. J. Biol. Macromol. 94:271-82.

20. Poiroux, G., Barre, A., Van Damme, E.J., Benoist, H. and Rougé, P. (2017). Plant lectins targeting O-glycans at the cell surface as tools for cancer diagnosis, prognosis and therapy. Int. J. Mol.Sci. 18(6):1232.

21. Pratt, J., Roy, R. and Annabi, B. (2012). Concanavalin-A-induced autophagy biomarkers requires membrane type-1 matrix metalloproteinase intracellular signaling in glioblastoma cells. Glycobiology. 22(9):12451255.

22. Sharon, N. (2007). Lectins: carbohydratespecific reagents and biological recognition molecules. J. Biol. Chem. 282(5):2753-2764.
23. Shi, Z., Chen, J., Li, C.Y., An, N., Wang, Z.J., Yang, S.L., Huang, K.F. and Bao, J.K. (2014). Antitumor effects of concanavalin A and Sophora flavescens lectin in vitro and in vivo. Acta Pharmacol. Sin. 35(2):248-256.

24. Sumner, J.B. and Howell, S.F. (1936). Identification of hemagglutinin of jack bean with concanavalin A. J. Bacteriol. 32(2):227.

25. Suvarna, G. and Sharma, B.B. (2018). Concanavalin-a potential glycoprotein. J. Proteins Proteom. 9(2):77-90.

26. Suvarna, G. and Sharma, B.B. (2020). An analogy of Canavalia lectins by molecular phylogenetic characterization. J. Proteins Proteom. 11(3):193-203.

27. Terho, P. (2012). Flowing software, Cell Imaging Core of the Turku Centre for Biotechnology, Turku, Finland.

28. Une, S., Nonaka, K. and Akiyama, J. (2018). Lectin isolated from Japanese red sword beans (Canavalia gladiata) as a potential cancer chemopreventive agent. J. Food Sci. 83(3):837843.

29. Waterborg, J.H. and Matthews, H.R. (1994). The Lowry method for protein quantitation. Methods Mol Biol. 32:1-4.

30. Wong, J.H. and Ng, T.B. (2005). Isolation and characterization of a glucose/mannose/ rhamnose-specific lectin from the knife bean Canavalia gladiata. Arch. Biochem. Biophys. 439(1):91-98. 